\title{
PRODUCTION LOW-FAT BEEF BURGER BY USING GUM ARABIC AS FAT REPLACER
}

\author{
M.E. El-Sayed ${ }^{(1)}$, A.S. Bakr ${ }^{(1)}$, A.M. Gaafar ${ }^{(2)}$, Awatef I. Ismaiel ${ }^{(2)}$ \\ and M. M. Salem ${ }^{(2)}$ \\ (1) Food Sci \& Technol. Dept. Fac. Agric. Tanta University. \\ ${ }^{(2)}$ Food Technology Research Institute, Agricultural, Research, Center, Giza, Egypt.
}

Received: Apr. 2 , 2020

Accepted: Apr. 7,2020

\begin{abstract}
The chemical composition, phenolic compounds and antioxidant activity of Gum Arabic (GA) were studied, as were physical, chemical, cooking and sensory properties of low-fat beef burger manufactured by replacing its fat content with different levels $(0.0,5,10,15$ and $20 \%)$ of GA. The results of chemical composition of GA indicated that the total dietary fiber was the major compound (89.89\%) and the other components were minor such as protein (2.02\%), ash (3.99\%), and ether extract (4.10\%). The present study showed that antioxidant activity of GA extracted by water (73.30\%) was higher than extracted by ethanol (70.87\%). All chemical compositions (moisture, fiber, protein, ash and total carbohydrate contents) of uncooked and cooked low-fat beef burger manufactured by replacing its fat content with different levels of GA were increased, except ether extract content was decreased. However, replacing process increased $(P \leq$ $0.05)$ significantly of both water holding capacity and feder value, it was decreased $(P \leq$ $0.05)$ significantly of plasticity, protein water coefficient and protein-water-fat coefficient of low-fat beef burger. Cooking properties were affected by replacing fat with GA whereas, cooking yield was increased $(P \leq 0.05)$, and on the other side cooking loss, shrinkage and diameter reduction were significantly $(P \leq 0.05)$ decreased. Sensory evaluation of low-fat beef burger showed the level replacement 5 and $10 \%$ of GA produced beef burger similar with control with little changes also 15 and 20\% replacement gave a fair low-fat beef burger.
\end{abstract}

Key word: Gum Arabic, beef burger, antioxidant activity, chemical and physical properties.

\section{INTRODUCTION}

Gum Arabic is edible biopolymer obtained as exudates of mature tress of Acacia senegal which grow principally in the Africa region of Sahel in Sudan. The exudates are a non-viscous liquid, rich in soluble fibers, and its emanation from the stems and branches usually occurs under stressful conditions such as draught, poor soil fertility, and injury (Williams and Philliphs, 2000). Gum Arabic is a branched-chain, complex polysaccharides, either neutral or slightly acidic, found as a mixed of calcium, magnesium, potassium salt of a polysaccharide acid (glucuronic acid).
Gum Arabic has been claimed to act an antioxidant, and to protect against experimental hepatic-, renal and cardiac toxicities (Ali et al., 2009). Gum Arabic also considered in folk medicine to treat diabetes mellitus. The plant has been shown to exhibit antibacterial, antifilamentary, vasoconstrictor actions, antihypertensive, antispasmodic activities, inhibitory effect against hepatitis virus, cytotoxic activities and antioxidant activity (Gilani et al., 1999 and Malviya et al., 2011).

Food manufactures have responded to consumer demand and there has been a rapid market growth of products with a 
healthy image (Liu et al., 2007). One of the major trends is to reduce the fat content of traditional dressing foods, which has led to popular "reduced fat", "light", "low fat", or "fat free" versions of these traditional products. However, as a food component, fat contributes to the flavor, appearance, texture and shelf life of food products. Therefore, it is difficult to imitate traditional product quality when preparing reduced-fat foods. Thus, to establish the formulation of reducedfat products, it is necessary to use a combination of non fat ingredients with different functional roles to replace the quality attributes lost when fat is removed. Thus to establish the formulation of the low fat products, food technologists have focused their efforts essentially on fat replacers (Liu et al., 2007). The reduced of fat and calorie derived from the use of fat replacers is a nutritional approach to prevent many chronic diseases (i-e cardiovascular disease, hypertension, obesity .........), thus providing beneficial health effect (Lim et al., 2010). Biopolymers, such as gums, starches and proteins are often incorporated into fat-reduced products to provide some of these functional attributes (Mun et al., 2009).

In recent years, health concerns about fat consumption and changes in consumer's preferences have led to extensive research on low-fat foods (Carrapiso, 2007). The popularity of hamburger lies in it is favorable a sensory characteristics practicality and high content of protein with high biological value, vitamins and minerals (Ramadhan et al., 2011). This research aimed to study the active ingredients of GA and investigate the effect of partial replacing of fat content with GA on the physical, chemical and sensory evaluation of low-fat beef burger.

\section{MATERIALS AND METHODS}

\section{Materials:}

\section{Gum Arabic:}

Gum Arabic (Acacia senegal, Hashab) in powder form was obtained from Samandal Company for Export and Import, Sudan.

\section{Beef meat and other ingredients:}

Lean beef, kidney fat and other ingredients (spices mixture, salt, dried onion and dried garlic) were obtained from local market at Tanta City, Egypt.

\section{Gross chemical composition:}

Moisture, crude protein, ether extract, ash and crude fiber were determined according to AOAC (2005). Total dietary fiber content was calculated by differences subtracting protein; ash and ether extract content from the total mass of $100 \mathrm{~g}$ as reported by Sabah El-Kheir et al. (2008).

Determination of total phenolics content (TPC):

Total phenolic content was determined by the Folin-Ciocalteu method according to Arabshahi-Delouee and Urooj (2007). Total phenolic content expressed as Gallic acid equivalent ( $g$ / $100 \mathrm{~g}$ dry weight).

\section{Separation and identification of phenolic compounds by using HPLC:}

Phenolic compounds of GA ethanol extract was separated and identified by HPLC apparatus (Type: Shimadzu LC-6A model) in Central Laboratory of Food Tech. Res. Inst., Agric. Res. Center, Giza, Egypt according to the method of Goupy et al. (1999) under the following conditions: Column: Water-Bondapack C18 column $(250 \times 4.6 \mathrm{~mm})$ and as SCL6A system controller; the solvent system used was a gradient of $A(\mathrm{CH} 3 \mathrm{COOH}$ 
2.5\%), B (CH3COOH $8 \%)$ and C (acetonitrile). The solvent flow rate was $0.7 \mathrm{ml} / \mathrm{min}$ and separation was performed at $35^{\circ} \mathrm{C}$; injection volume: 20 $\mu \mathrm{l}$; detector: UV-visible spectrophotometer SPD- $6 \quad$ AV (Leicestershine LE17 5BH, UK); phenolic compounds were assayed by external standard calibration at $280 \mathrm{~nm}$ and expressed in $\mu \mathrm{g} / \mathrm{L}-1$ equivalent (+)catechin.

\section{Evaluation of Antioxidant activity of extracts (AA):}

The antioxidant activity was evaluated by 1,1-diphenyl-2-picrylhydrazyl (DPPH) radical scavenging method according to the procedure of Lee et al. (2003). The antioxidant activity was expressed as the percentage of decline of the absorbance relative to the control, corresponding to the percentage of DPPH that was scavenged. Scavenging activity was calculated as follows:

DPPH radical-scavenging activity $(\%)=$ [(A control - A sample) $/$ / (A control) $] \times 100$ Where, $A$ is the absorbance at $515 \mathrm{~nm}$.

IC50 values, which correspond to the concentration of Gum Arabic extracts that caused a $50 \%$ neutralization of DPPH, were calculated from the plot of percent DPPH scavenging versus concentration.

\section{Preparation of beef burger:}

Beef burger samples were formulated according to Aleson-Carbonell et al. (2005) from fresh lean beef and kidney fat and the ingredients were tabulated in Table (A).

The lean beef and kidney fat sources were separately ground in 5-mm plate in meat grinder (Braun multi - Quick system $1002 k$ ) and then the water, salt and spice mixture were added and mixed with ground meat and fat for $4 \mathrm{~min}$. The mixture was divided into five proportions. The first proportion was served as control. For each treatment the mixture was mixed individually by rehydrated GA at different levels 5, 10, 15 and $20 \%$ (fat weight basis), and then mixed again for $5 \mathrm{~min}$ to create homogenate mixture. Patties were placed on plastic foam meat trays, wrapped with polyethylene film and kept frozen at $\left(-18^{\circ} \mathrm{C}\right)$ until further analysis.

The beef burger samples were grilled on an electrical hot plate at $180^{\circ} \mathrm{c}$ for 5 min, Khalifa (2011).

Table (A): Ingredients for prepared beef burger containing GA at different levels ( $\mathrm{g} / \mathbf{1 0 0 g}$ ).

\begin{tabular}{|l|c|c|c|c|c|}
\hline \multirow{2}{*}{ Ingredients } & \multicolumn{5}{|c|}{ Gum Arabic levels (\%) } \\
\cline { 2 - 6 } & 0 & $5 \%$ & $10 \%$ & $15 \%$ & $20 \%$ \\
\hline Beef meat & 65.00 & 65.00 & 65.00 & 65.00 & 65.00 \\
\hline Beef fat & 15.00 & 14.25 & 13.50 & 12.75 & 12.00 \\
\hline Water & 10.50 & 10.50 & 10.50 & 10.50 & 10.50 \\
\hline Spice mixture & 2.50 & 2.50 & 2.50 & 2.50 & 2.50 \\
\hline Dried onion & 2.50 & 2.50 & 2.50 & 2.50 & 2.50 \\
\hline Dried garlic & 2.50 & 2.50 & 2.50 & 2.50 & 2.50 \\
\hline Salt & 2.00 & 2.00 & 2.00 & 2.00 & 2.00 \\
\hline Gum Arabic & 0.00 & 0.75 & 1.50 & 2.25 & 3.00 \\
\hline
\end{tabular}


M.E. El-Sayed, et al.,

Physical properties and feder value:

Water holding capacity (WHC) and plasticity:

Water holding capacity (WHC) and plasticity were measured using the method of El-Seesy (2000) using the following equation:

Free water

$=\frac{(\text { Total surface area }- \text { meat film area,mm })(6.11)}{(\text { Total moisture }(\mathrm{mg}) \text { in meat sample })} \times 100$

WHC $(\%)=100-$ free water

Plasticity $\left(\mathrm{cm}^{2}\right)=$ Meat film area (Internal area)

\section{Texture indices:}

Protein water coefficient (PWC) and protein-water-fat coefficient (PWFC) were calculated according to Tsolaze (1972) using the following equations:

PWC $=\frac{\% \text { protein }}{\% \text { water }}$

PWFC $=\frac{\% \text { protein }}{\% \text { water }+\% \text { fat }}$

\section{Feder value:}

Feder value which is used for assessing one of the quality attributes in meat was calculated according to Pearson (1991) using the following equation:

Feder value $=\frac{\% \text { water }}{\% \text { organic non fat }}$

Where $\%$ organic non fat $=$

$$
100-(\% \text { Moisture + } \% \text { Fat + } \% \text { Ash })
$$

\section{Cooking characteristics:}

\section{Texture profile analysis:}

Texture was determined in Food Technology Research. Institute, Agricultural Research Center GizaEgypt, by a universal testing machine (Cometech, B type, Taiwan) provided with software. An Aluminum $25 \mathrm{~mm}$ diameter cylindrical probe was used in a "Texture Profile Analysis" (TPA) double compression test to penetrate to $50 \%$ depth, at $1 \mathrm{~mm} / \mathrm{s}$ speed test. Hardness $\left(\mathrm{N} / \mathrm{cm}^{2}\right)$, gumminess $\left(\mathrm{N} / \mathrm{cm}^{2}\right)$, chewiness $\left(\mathrm{N} / \mathrm{cm}^{2}\right), \quad$ cohesiveness (ratio), springiness and resilience were calculated from the TPA graphic. Both, springiness were calculated from the TPA graphic as described by Bourne (2003).

\section{Shrinkage:}

Shrinkage percentage was calculated as described by American Meat Science Association (1995) as follows:

$\%$ Shrinkage

$=\frac{\text { (Raw thickness }- \text { Cooked thickness })+(\text { Raw diameter }- \text { Cooked diameter })}{}$ (Raw thickness +Raw diameter)

\section{Diameter reduction:}

Changes in beef burgers diameter was calculated by Gök et al. (2011) using the following equation:

$\%$ Diameter reduction

$$
=\frac{\text { (Uncooked diameter }- \text { Cooked diameter })}{\text { Uncooked diameter }} \times 100
$$

\section{Cooking loss:}

Cooking loss of the beef burger was calculated according to American Meat Science Association (1995) using the following equation:

$$
\begin{aligned}
& \text { Cooking loss (\%) } \\
& =\frac{[\text { Raw sample weight }(\mathrm{g}) \text {-Cooked sample (g) }]}{\text { Raw sample weight }(\mathrm{g})}
\end{aligned}
$$

\section{Cooking yield:}

Cooking yield of the beef burger was determined by measuring the weight of three burgers for each treatment/batch Gök et al. (2011) and calculating weight differences for burgers before and after cooking, as follows: 
Cooking yield (\%)

$$
=\frac{\text { Cooked weight }(\mathrm{g})}{\text { Raw weight }(\mathrm{g})} \times 100
$$

pH value:

The $\mathrm{pH}$ value of samples was measured using the method described by Bloukas et al. (1997) using electronic electrode of digital pH-meter (JENCO 608 U.S.A).

\section{Organoleptic evaluation:}

Cooked burger samples were subjected to sensory evaluation directly for color, texture, taste, tenderness, appearance and overall acceptability by trained panel consisted of twenty members of Food Technology Research Institute (FTRI) selected from laboratory staff. Hedonic scale rating 1-10 points (1 = dislike very much; 10=like very much) to assess the differences Smith et al. (1973). Panelists evaluated of cooked burger samples which were offered at the same time in specific area of sensory test without special lighting. Water was provided for rinsing purposes.

\section{Statistical analysis:}

Statistics on a completely randomized design were performed with the analysis of variance (ANOVA) procedure in SPSS (Version 16.0, SPSS Inc., Chicago, IL) software. Duncan's multiple range test
( $p>0.05$ ) was used to detect differences among mean values SPSS (2009).

\section{RESULTS AND DISCUSSION}

\section{Chemical composition of Gum} Arabic:

Results of gross chemical composition of GA are show in Table (1). The GA contain a great amount of total dietary fiber, it represents about $83.41 \%$ of total chemical composition on wet weight and about $89.89 \%$ on dry weight basis. Also, GA contain a small amounts of ether extract and ash, which represent about 3.70 and $3.80 \%$ on wet weight and about 3.99 and $4.10 \%$ on dry weight, respectively while protein content recorded the lowest amount of chemical composition, it represent about 1.87 and 2.02 of total chemical composition on wet and dry weight basis, respectively. The results of ash, lipid and total dietary fiber are in full agreement with that obtained by Sabah El-Kheir et al. (2008); Nasir et al. (2012); Dauqan and Abdullah (2013) and Abd El-Shakour (2014). Whereas, protein content is agreeing with the results of Daoub et al. (2016), but lower than that obtained by Abd El-Shakour (2014). Al-Assaf et al. (2005) stated that the chemical composition of GA can vary with it is source, the age of trees which it was obtained, climatic condition and soil environment.

Table (1): Chemical composition of Gum Arabic ( $\mathrm{g} / \mathbf{1 0 0 g}$ ).

\begin{tabular}{|l|c|c|}
\hline \multirow{2}{*}{ Constituents } & \multicolumn{2}{|c|}{ Percentage of constituents } \\
\cline { 2 - 3 } & On wet weight basis & On dry weight basis \\
\hline Moisture & 7.22 & - \\
\hline Protein & 1.87 & 2.02 \\
\hline Lipids & 3.70 & 3.99 \\
\hline Ash & 3.80 & 4.10 \\
\hline Total dietary fiber & 83.41 & 89.89 \\
\hline
\end{tabular}

* Calculated by differences as the flowing equation; 100- (moisture+ protein+ lipid+ ash). 
M.E. El-Sayed, et al.,

Separation and identification of phenolic compounds of GA by using HPLC:

Fractionation and identification of total phenolic compounds of GA ethanol extract by using HPLC are given in Table (2). Data revealed that total phenolic compounds content of GA was 1449.35 $\mathrm{mg} / \mathbf{1 0 0 \mathrm { g }}$. This result is in full agreement with those obtained El-Tobgy (2019), who found that total phenolic content of dried exudates (gum) from Acacia senegal purchased from Aswan city was 1.526 $\mathrm{g} / \mathbf{1 0 0 g}$. HPLC chromatogram reveled that GA extract contain several phenolic acids: hydroxybenzoic acid (i.e, gallic, benzoic, vanillic and salycilic) and hydroxycinnamic acids (i.e cinnamic, caffeic and P.coumaric acid). Besides these phenolic acids, many phenolic compounds were also found i.e. Pyrogallol, Catechein, epicatechein, catechol and derivatives of phenolic acids.

GA extract contains catechein as a predominant phenolic compound recording $445.21 \mathrm{mg} / 100 \mathrm{~g}$, followed by epicatechein $(108.08 \mathrm{mg} / 100 \mathrm{~g})$ and gallic acid $(161.45 \mathrm{mg} / 100 \mathrm{~g})$. These three components represent more than $50 \%$ of total phenolic compounds (54.28\%), another four components: pyrogallol, vanillic acid salycilic acid and catechol recording 93.42, 91.85, 77.12 and 69.42 $\mathrm{mg} / \mathbf{1 0 0 \mathrm { g }}$, respectively which represent $22.89 \%$ of total phenolic compounds. The other seven components represent about $22.83 \%$. The present findings are in complete agreement with study conducted by El-Tobgy (2019), who found that catechein, epicatechein and gallic acid the predominant compounds in GA.

Table (2): Identification of phenolic compound of sample $(\mathrm{mg} / \mathbf{1 0 0 \mathrm { g }})$ by HPLC of Gum Arabic.

\begin{tabular}{|l|c|}
\hline Phenolic compounds & $(\mathrm{mg} / 100 \mathrm{~g})$ \\
\hline Gallic acid & 161.45 \\
\hline Pyrogallol & 93.42 \\
\hline Catechein & 445.21 \\
\hline Epicatechein & 180.08 \\
\hline Quinic acid & 3.98 \\
\hline Catechol & 69.42 \\
\hline 3-methoxybenzoic acid & 40.54 \\
\hline Tannic acid & 10.31 \\
\hline Benzoic acid & 40.09 \\
\hline Caffeic acid & 1.94 \\
\hline Vanillic acid & 91.85 \\
\hline p-Coumaric acid & 7.54 \\
\hline Cinnamic acid & 5.27 \\
\hline Salycilic acid & 77.12 \\
\hline Other compounds & 221.13 \\
\hline Total phenolic compound & 1449.35 \\
\hline
\end{tabular}




\section{Antioxidant activity of GA extracts:}

The results obtained from the DPPH radical experiments were expressed as the percentage of decline of the absorbance relative to the control are presented in Table (3). The DPPH radical scavenging activity of water extract and $50 \%$ ethanolic extract were 73.30 and $70.87 \%$, respectively. The results are higher than that reported by El-Tobgy (2019), who revealed that the DPPH free radical scavenging activity of GA purchased from Aswan was $66.707 \%$. The IC50 of GA water extract and ethanolic extract were 18.27 and 22.39 $\mathrm{mg} / \mathrm{ml}$, respectively. The value of IC50 of water extract was lower than IC50 of ethanolic extract; this may be due to the differences in phenolic content of water extract and ethanolic extract.

\section{Chemical composition of beef burger:}

The results of chemical composition of both uncooked and cooked beef burger manufactured by replacing fat content with different levels $(0.0,5,10,15$ and $20 \%$ ) of GA are shown in Table (4). Moisture content of uncooked and cooked beef burger was increased $(P \leq$ $0.05)$ gradually as a function of increasing the percentage of GA replacement level to beef burger. Beef burger manufactured without any addition of GA (control) had the lowest ( $P$ $\leq 0.05$ ) significantly value of moisture content in both raw and cooked beef

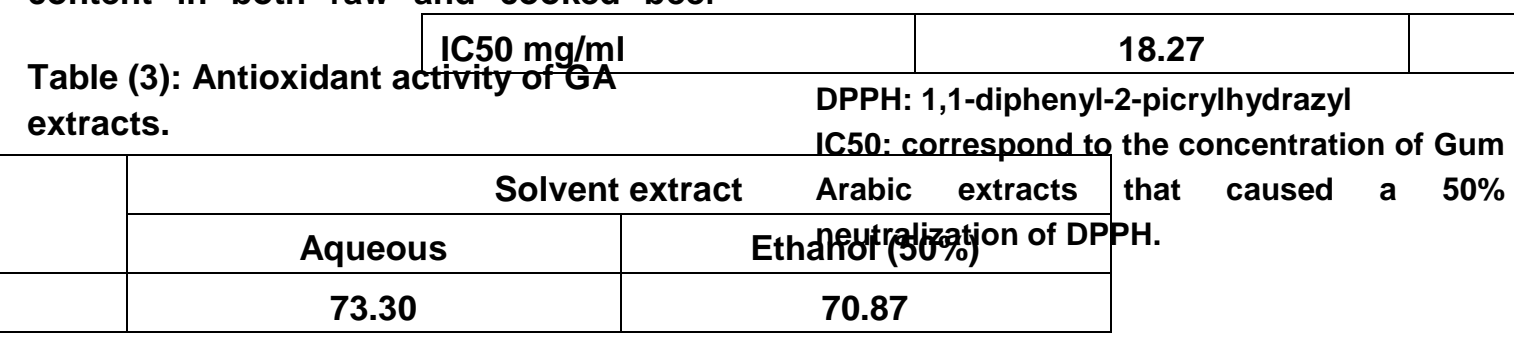

burger. Also, the moisture content of beef burger samples determined after cooking process were lower than that of raw beef burger. The decrements of moisture content of cooked beef burger due to cooking and evaporation of moisture during cooking process. The increment of moisture content may be due to the capability of GA rich with fiber to hold more water via preparation and cooking process. These results are in agreement with Choi et al. (2016) they stated that, dietary fiber sources has the capacity to hold three or four times its weight of water.

Protein content of the fat replaced uncooked and cooked beef burger was replacement levels increased of GA. The same trend was noticed by Hussein et al. (2015), who found that the protein content of law fat sausage prepared with fat replacer increased by increasing substitution ratio.

Fat content of control uncooked and cooked beef burger had higher ( $P \leq 0.05)$ amount of fat than that of other treatments. Furthermore, fat content of all beef burger containing GA with different levels as fat replacer decreased ( $p \leq 0.05$ ) significantly with increasing of replacement level of GA. Mansour and Khalil (1997) and Gad (2019) reported that there were significantly decreased in fat content for beef burger with added wheat dietary fiber and GA. increased $(P \leq 0.05)$ significant as the 


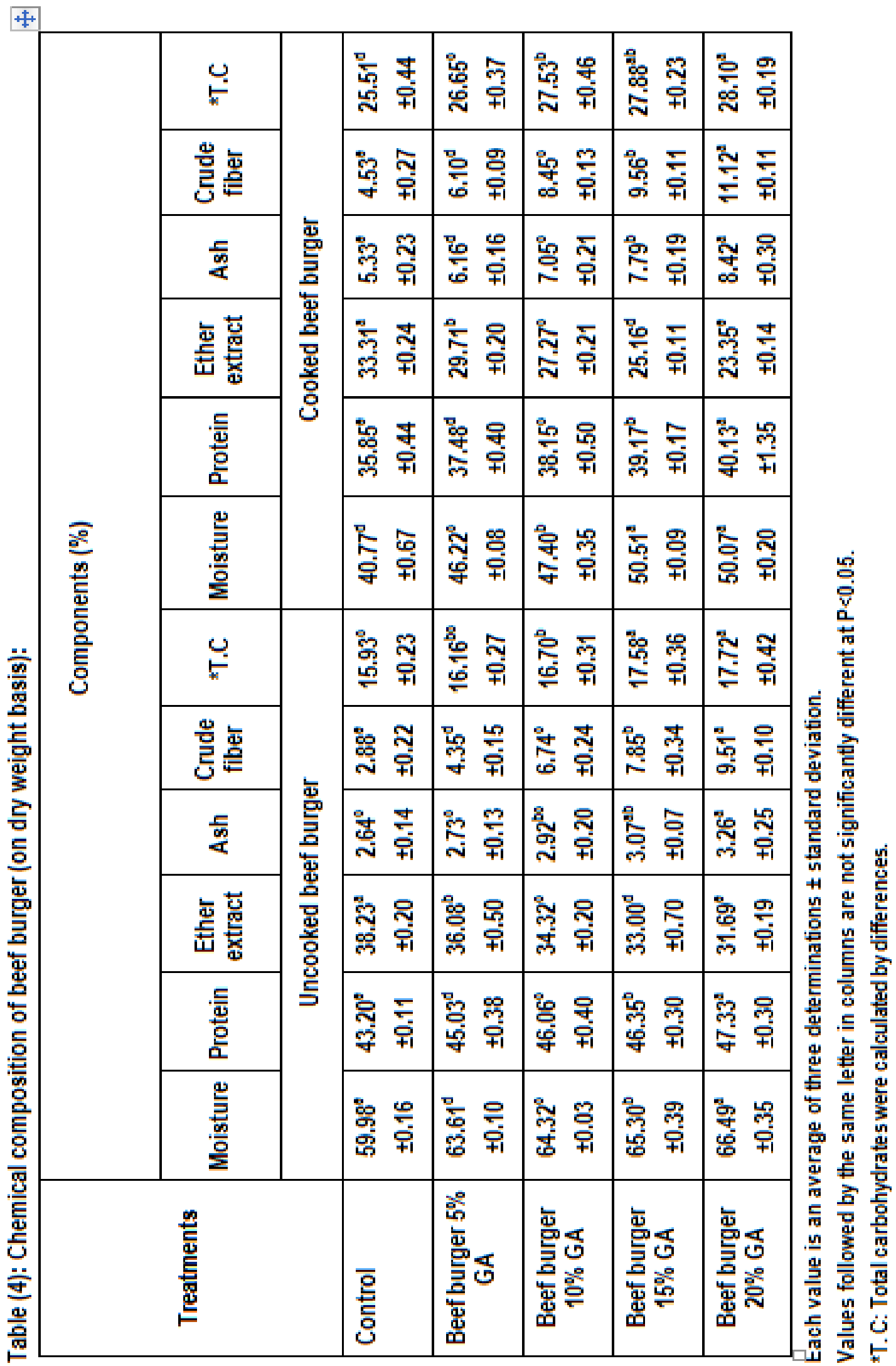


Ash content percentage of uncooked and cooked beef burger was increased $(P$ $\leq 0.05$ ) significantly as a function of increasing the percentage of GA replacement level to beef burger. This increment may be due to high ash content of GA in comparing with that of control beef burger. Ash content of reduced-fat chicken patties samples containing wheat sprout was higher than those of control patties Choi et al. (2016).

Crude fiber content was significantly $(P \leq 0.05)$ increased by increasing fat replacement levels of GA. This increment may be due to high crude fiber content of GA. Data of the present study are in agreement with those found by Hussein et al. (2015) and Mwove et al. (2016). The ratios of fat replacers increased the total carbohydrates of beef burger was increased with a significant $(P \leq 0.05)$ difference in comparison with control beef burger. Also, the results revealed that, cooked beef burger have percentages of moisture, ether extract and protein lower than uncooked beef burger with significant $(P \leq 0.05)$ differences between samples. Meanwhile, the opposite were found in case of ash, crude fiber and total carbohydrate increased, this also was probably due to the moisture loss during cooking process Mansour and khalil, (1997) and Gad (2019).

\section{Physical properties and feder value of beef burger:}

Data in Table (5) showed the physical properties of beef burger containing GA with different levels. Water holding capacity (WHC) was increased ( $P \leq 0.05)$ significantly with increasing the replacement level. The highest WHC was observed in both $20 \%$ and $15 \%$ replacement level $(63.50 \%$ and $63.42 \%$, respectively) followed by $10 \%(62.32 \%)$ and finally $5 \%(60.51 \%)$, while WHC for control beef burger was $56.33 \%$. This result is probably due to the ability of GA to absorb large amounts of water. Generally, this finding agrees well with those reported by Mahmoud et al. (2017). The values of protein water coefficient (PWC) and protein water fat coefficient (PWFC); which are considered as indices for tenderness of the prepared beef burger, were decreased $(P \leq 0.05)$ gradually with the increasing of GA levels comparing to control sample. These decrements relate to the increase occurred in moisture content. These results were in agreement with those published by Bessar (2008). Also, plasticity $\left(\mathrm{cm}^{2}\right)$ value of beef burger enriched with different levels of GA is decreased $(P \leq 0.05)$ gradually with increasing the replacement level of GA. These results agreement with those published EL-Refai et al. (2011) and Shalaby et al. (2015). Also, feder value; which is used for assessing the physical properties of meat products, was $\mathbf{1 . 6 0 3 3}$ for control sample of burger. Feder values of burger increased ( $P \leq 0.05$ ) gradually with increasing the replacement level of GA. All values of feder values were kept under 4.0. According to Pearson (1991), the feder number in good quality product should not exceed 4.0. These increments in feder number may be due to the increase in water content as a result to increase GA which content high amount of dietary fiber.

\section{Cooking properties and $\mathrm{pH}$ value of beef burger:}

The results of cooking properties (cooking shrinkage, diameter reduction, cooking yield and cooking loss) and $\mathrm{pH}$ values of beef burger manufactured by replacing fat content with different levels of GA are shown in Table (6). Significant $(P \leq 0.05)$ differences were observed among beef burger control sample and 
M.E. El-Sayed, et al.,

all low fat beef burger formulas prepared with GA for cooking properties. Apparent also from the negative correlation between cooking yield and cooking loss of all samples, however cooking loss of beef burger enriched with different levels of $G A$ is decreased $(P \leq 0.05)$ with increasing the addition levels since beef burger enriched with GA had cooking loss values lower $(P \leq 0.05)$ than that of control. This may be related to the fiber content of GA which could influence the cooking loss of the beef burger, since fibers could reduce the water loss during cooking by forming gels as reported by Namir et al. (2015).

Table (5): Physical properties and feder value of beef burger.

\begin{tabular}{|l|c|c|c|c|c|}
\hline Treatments & WHC \% & Plasticity & PWC & PWFC & $\begin{array}{c}\text { Feder } \\
\text { value }\end{array}$ \\
\hline Control & $\begin{array}{c}56.33 \mathrm{~d} \\
\pm 0.57\end{array}$ & $4.56 \mathrm{a} \pm 0.11$ & $\begin{array}{c}0.289 \mathrm{a} \\
\pm 0.006\end{array}$ & $\begin{array}{c}0.235 \mathrm{a} \\
\pm 0.005\end{array}$ & $\begin{array}{c}1.603 \mathrm{~d} \\
\pm 0.03\end{array}$ \\
\hline Beef burger 5\% GA & $\begin{array}{c}60.51 \mathrm{e} \\
\pm 0.20\end{array}$ & $\begin{array}{c}4.41 \mathrm{~b} \\
\pm 0.16\end{array}$ & $\begin{array}{c}0.284 \mathrm{ab} \\
\pm 0.002\end{array}$ & $\begin{array}{c}0.231 \mathrm{ab} \\
\pm 0.001\end{array}$ & $\begin{array}{c}1.623 \mathrm{~d} \\
\pm 0.02\end{array}$ \\
\hline Beef burger 10\% GA & $\begin{array}{c}62.32 \mathrm{~b} \\
\pm 0.32\end{array}$ & $\begin{array}{c}4.23 \mathrm{bc} \\
\pm 0.09\end{array}$ & $\begin{array}{c}0.278 \mathrm{~b} \\
\pm 0.002\end{array}$ & $\begin{array}{l}0.228 \mathrm{~b} \\
\pm 0.002\end{array}$ & $\begin{array}{c}1.677 \mathrm{c} \\
\pm 0.05\end{array}$ \\
\hline Beef burger 15\% GA & $\begin{array}{c}63.42 \mathrm{a} \\
\pm 0.42\end{array}$ & $\begin{array}{c}4.05 \mathrm{~cd} \\
\pm 0.07\end{array}$ & $\begin{array}{c}0.270 \mathrm{c} \\
\pm 0.005\end{array}$ & $\begin{array}{c}0.223 \mathrm{c} \\
\pm 0.001\end{array}$ & $\begin{array}{c}1.777 \mathrm{~b} \\
\pm 0.05\end{array}$ \\
\hline Beef burger 20\% GA & $63.50 \mathrm{a}$ & $3.86 \mathrm{c} \pm 0.10$ & $0.250 \mathrm{~d}$ & $0.212 \mathrm{~d}$ & $2.090 \mathrm{a}$ \\
& \pm 0.20 & & \pm 0.002 & \pm 0.008 & \pm 0.01 \\
\hline
\end{tabular}

Each value is an average of three determinations \pm standard deviation.

Values followed by the same letter in columns are not significantly different at $P<0.05$.

WHC= Water Holding Capacity; PWC= Protein-Water Coefficient; PWFC= Protein-Water-Fat Coefficient.

Table (6): Cooking properties and $\mathrm{pH}$ values of beef burger:

\begin{tabular}{|l|c|c|c|c|c|}
\hline \multicolumn{1}{|c|}{ Treatments } & $\begin{array}{c}\text { Cooking } \\
\text { loss (\%) }\end{array}$ & $\begin{array}{c}\text { Cooking } \\
\text { yield (\%) }\end{array}$ & $\begin{array}{c}\text { Shrinkage } \\
(\%)\end{array}$ & $\begin{array}{c}\text { Diameter } \\
\text { reduction } \\
(\%)\end{array}$ & $\mathrm{pH}$ \\
\hline Control & $27.44^{\mathrm{a}}$ & $72.56^{\mathrm{d}}$ & $19.44^{\mathrm{a}}$ & $16.84^{\mathrm{a}}$ & $5.47^{\mathrm{a}}$ \\
& \pm 0.11 & \pm 0.11 & \pm 0.29 & \pm 0.09 & \pm 0.07 \\
\hline Beef burger 5\% GA & $20.60^{\mathrm{b}}$ & $79.40^{\mathrm{c}}$ & $14.50^{\mathrm{b}}$ & $12.88^{\mathrm{b}}$ & $5.70^{\mathrm{a}}$ \\
& \pm 0.10 & \pm 0.10 & \pm 0.08 & \pm 0.11 & \pm 0.09 \\
\hline Beef burger 10\% GA & $19.40^{\mathrm{c}}$ & $80.60^{\mathrm{b}}$ & $13.20^{\mathrm{c}}$ & $12.25^{\mathrm{c}}$ & $5.70^{\mathrm{a}}$ \\
& \pm 0.27 & \pm 0.27 & \pm 0.18 & \pm 0.08 & \pm 0.13 \\
\hline Beef burger 15\% GA & $19.25^{\mathrm{c}}$ & $80.75^{\mathrm{b}}$ & $12.96^{\mathrm{c}}$ & $12.12^{\mathrm{cd}}$ & $5.62^{\mathrm{a}}$ \\
& \pm 0.21 & \pm 0.21 & \pm 0.15 & \pm 0.10 & \pm 0.08 \\
\hline Beef burger 20\% GA & $18.50^{\mathrm{d}}$ & $81.50^{\mathrm{a}}$ & $11.80^{\mathrm{d}}$ & $12.01^{\mathrm{d}}$ & $5.48^{\mathrm{a}}$ \\
& \pm 0.03 & \pm 0.03 & \pm 0.24 & \pm 0.05 & \pm 0.23 \\
\hline
\end{tabular}

Each value is an average of three determinations \pm standard deviation

Values followed by the same letter in columns are not significantly different at $P<0.05$ 
Cooking yield of beef burger enriched with different levels of GA is increased ( $P$ $\leq 0.05$ ) with increasing the addition levels, since beef burger enriched with GA had cooking yield values higher than that of control. Burger containing $20 \%$ (GA) had the highest cooking yield value $(81.50 \%)$ while control had the lowest value $(72.56 \%)$. This may be related to the fibers content of GA which could influence the cooking yield of the beef burger, since fibers could reduce the water loss during cooking by forming gels as reported by Rather et al. (2016).

Control beef burger sample had a high $(P \leq 0.05)$ percentage of shrinkage and diameter reduction after cooking process in a comparison with burger integrated with GA. These results are in conformity with the finding stated by Namir et al. (2015) and Gad (2019). The control sample had highest values of shrinkage, diameter reduction and cooking loss (19.44, 16.84 and $27.44 \%$ respectively). On the other hand, using GA at different levels improved the shrinkage, diameter reduction and cooking loss of low fat beef burger in compare with those of high fat beef burger control. These results are in harmony with those of Gibis et al., (2015), who reported that less shrinkage, diameter reduction and cooking loss in low-fat lamb patties containing CMC compared with control beef burger.

$\mathrm{pH}$ value is one of the most important factors that effect on several properties of meat products, for example color, shelf-life, texture and water holding capacity (El-Abd et al., 2003; Simela, 2005 and Hashem et al., 2011). No significant $(P \leq 0.05)$ differences were noticed in $\mathrm{pH}$ among beef burger control (5.47) and that formulated with different replacement levels of GA. These results are similar to those reported by El-Beltagy et al. (2007).

\section{Texture profile analysis of beef burger:}

The results of replacing fat content with GA at different levels on texture profile (hardness, cohesiveness, springiness, gumminess and chewiness) of beef burger are show in Table (7).

Hardness, springiness, gumminess, and chewiness values of cooked beef burger significantly $(P \leq 0.05)$ increased with increasing levels of GA. The highest values were noticed in cooked beef burger manufactured with $20 \%$ GA (19.960, $0.793, \quad 9.88$ and 7.806 respectively) while, lowest values were noticed in control sample $(18.650,0.730$, 8.740 and 6.390 respectively) compared to all samples. Non significant $(P \geq 0.05)$ differences were observed with increasing the levels of GA replacer in cohesiveness values of all beef burger samples. The improvement in textural properties may due to the dietary fiber which has abilities of binding water and fat absorption (Choi et al., 2016). Demiric et al. (2014) found that addition of xanthan and guar gum to meatballs at $0.5,1.00$ and $1.50 \%$ improved the hardness and improved meatballs tissue. Also, Hussein et al. (2015) noticed that gumminess and cohesiveness of sausage were significantly increased by reducing fat level or increasing wheat bran or barely as fat replacer levels. Furthermore, the increase in springiness may be due to the gel network formed and increased water held by xanthan gum. On the other hand, the results showed that cohesiveness of cooked beef burger prepared with replace fat with different levels of GA had the opposite trend. The obtained data are consistent with Pereira et al. (2011); Yeo et al. (2014) and Gad (2019). 
M.E. El-Sayed, et al.,

Table (7): Texture profile analysis of beef burger.

\begin{tabular}{|c|c|c|c|c|c|}
\hline Treatments & $\begin{array}{c}\text { Hardness } \\
(\mathrm{N} / \mathrm{cm} 2)\end{array}$ & $\begin{array}{c}\text { Cohesiveness } \\
(\text { ratio })\end{array}$ & $\begin{array}{c}\text { Springiness } \\
(\mathrm{cm})\end{array}$ & $\begin{array}{c}\text { Gumminess } \\
(\mathrm{N} / \mathrm{cm} 2)\end{array}$ & $\begin{array}{c}\text { Chewiness } \\
(\mathrm{N} / \mathrm{cm} 2)\end{array}$ \\
\hline Control & $\begin{array}{c}18.650^{\mathrm{c}} \\
\pm 0.35\end{array}$ & $\begin{array}{c}0.493^{\mathrm{a}} \\
\pm 0.005\end{array}$ & $\begin{array}{c}0.730^{\mathrm{ab}} \\
\pm 0.010\end{array}$ & $\begin{array}{c}8.740^{\mathrm{bc}} \\
\pm 0.36\end{array}$ & $\begin{array}{c}6.390^{\mathrm{b}} \\
\pm 0.17\end{array}$ \\
\hline Beef burger 5\% GA & $\begin{array}{c}19.060^{\mathrm{bc}} \\
\pm 0.06\end{array}$ & $\begin{array}{c}0.493^{\mathrm{a}} \\
\pm 0.005\end{array}$ & $\begin{array}{c}0.730^{\mathrm{ab}} \\
\pm 0.011\end{array}$ & $\begin{array}{c}8.953^{\mathrm{bc}} \\
\pm 0.33\end{array}$ & $\begin{array}{c}6.596^{\mathrm{b}} \\
\pm 0.31\end{array}$ \\
\hline Beef burger 10\% GA & $\begin{array}{c}19.480^{\mathrm{ab}} \\
\pm 0.24\end{array}$ & $\begin{array}{c}0.473^{\mathrm{a}} \\
\pm 0.015\end{array}$ & $\begin{array}{c}0.703^{\mathrm{b}} \\
\pm 0.089\end{array}$ & $\begin{array}{c}9.220^{\mathrm{b}} \\
\pm 0.38\end{array}$ & $\begin{array}{c}6.460^{\mathrm{b}} \\
\pm 0.58\end{array}$ \\
\hline Beef burger 15\% GA & $19.910^{\mathrm{ab}}$ & $0.470^{\mathrm{a}}$ & $0.780^{\mathrm{ab}}$ & $9.816^{\mathrm{a}}$ & $7.656^{\mathrm{a}}$ \\
& \pm 0.11 & \pm 0.017 & \pm 0.010 & \pm 0.07 & \pm 0.12 \\
\hline Beef burger 20\% GA & $19.960^{\mathrm{a}}$ & $\begin{array}{c}0.470^{\mathrm{a}} \\
\pm 0.93\end{array}$ & $\begin{array}{c}0.793^{\mathrm{a}} \\
\pm 0.010\end{array}$ & $\begin{array}{c}9.886^{\mathrm{a}} \\
\pm 0.39\end{array}$ & $\begin{array}{c}7.806^{\mathrm{a}} \\
\pm 0.27\end{array}$ \\
\hline
\end{tabular}

Each value is an average of three determinations \pm standard deviation.

Values followed by the same letter in columns are not significantly different at $P<0.05$.

Coh = Cohesiveness; Gum= Gumminess; Che = Chewiness; Spr = Springiness .

\section{Sensory evaluation of beef burger:}

Data of sensory properties of beef burger as affected by replacing fat with GA at different levels were listed in Table (8). Significantly $(P<0.05)$ differences were observed in score values of color, taste, tenderness, texture, appearance and overall acceptability among control sample ( $0 \%$ GA level) of burger and that contained 5 and 10,15 and $20 \%$ GA as fat replacer for all sensory characteristics. Sensory characteristics of samples beef burger prepared using GA up to $10 \%$ ratio had nearly similar scores in compared with those of control of beef burger. Using of GA at the concentration of more than $10 \%$ led to decrease the scores for sensory characteristics of beef burger. The decrements with $20 \%$ represent about 18.0, 14.50, 10.70, 12.40, 11.25 and $10.70 \%$ of the control, that is mean all ratios of GA replacement can use for manufacture beef burger with overall acceptability more than $87.0 \%$ of the control. The highest values were noticed in control beef burger which was $8.80,9.00,9.08,8.70,8.78$ and 9.06 for color, taste, tenderness, texture, appearance and overall acceptability, respectively; while lowest values were noticed in beef burger contained $20 \%$ level GA which were 7.20, 7.70, 8.11, 7.62, 7.88 and 7.91 compared to all samples. These results are in agreement with those obtained by Soncu et al. (2015); Kılınççeker and Kurt (2016) and Gad (2019), who revealed that the decrease of appearance, color, flavor, texture and overall acceptability scores decreased with increasing levels of fiber. The obtained results are also particularly agreement with those of Mmove et al. (2016), who reported that the level of GA used in extended beef rounds significantly affected in all sensory attributes in cooked beef burger samples. 
Table (8): Sensory evaluation of beef burger manufactured with different levels of GA.

\begin{tabular}{|c|c|c|c|c|c|c|}
\hline Treatment & $\begin{array}{c}\text { Color } \\
(10)\end{array}$ & $\begin{array}{c}\text { Taste } \\
(10)\end{array}$ & $\begin{array}{c}\text { Tenderness } \\
(10)\end{array}$ & $\begin{array}{c}\text { Texture } \\
(10)\end{array}$ & $\begin{array}{c}\text { Appearance } \\
(10)\end{array}$ & $\begin{array}{c}\text { Overall } \\
\text { Acceptability } \\
(10)\end{array}$ \\
\hline Control & $8.80^{\mathrm{a}}$ & $9.00^{\mathrm{a}}$ & $9.08^{\mathrm{a}}$ & $8.70^{\mathrm{a}}$ & $8.78^{\mathrm{a}}$ & $9.06^{\mathrm{a}}$ \\
\pm 0.075 & \pm 0.53 & \pm 0.08 & \pm 0.11 & \pm 0.12 & \pm 0.09 \\
\hline $\begin{array}{c}\text { Beef burger } 5 \% \\
\text { GA }\end{array}$ & $8.47^{\mathrm{b}}$ & $8.68 \mathrm{~b}$ & $8.91^{\mathrm{ab}}$ & $8.50^{\mathrm{b}}$ & $8.77^{\mathrm{a}}$ & $8.90^{\mathrm{a}}$ \\
\hline Beef burger & \pm 0.26. & \pm 0.14 & \pm 0.31 & \pm 0.17 & \pm 0.11 & \pm 0.28 \\
\hline $10 \%$ GA & \pm 0.21 & $\mathbf{8 . 5 0 ^ { \mathrm { b } }}$ & $8.70^{\mathrm{b}}$ & $8.40^{\mathrm{b}}$ & $8.40^{\mathrm{b}}$ & $8.60^{\mathrm{b}}$ \\
\hline Beef burger & $7.80^{\mathrm{d}}$ & $8.08 \mathrm{c}$ & $8.40^{\mathrm{c}}$ & $8.40 \mathrm{c}$ & $8.40^{\mathrm{b}}$ & $8.52^{\mathrm{b}}$ \\
\hline $15 \%$ GA & \pm 0.07 & \pm 0.17 & \pm 0.26 & \pm 0.09 & \pm 0.22 & \pm 0.26 \\
\hline Beef burger & $7.20^{\mathrm{e}}$ & $7.70^{\mathrm{d}}$ & $8.11^{\mathrm{d}}$ & $7.62^{\mathrm{d}}$ & $7.88^{\mathrm{c}}$ & $7.91^{\mathrm{c}}$ \\
\hline $20 \%$ GA & \pm 0.08 & \pm 0.12 & \pm 0.16 & \pm 0.22 & \pm 0.09 & \pm 0.16 \\
\hline
\end{tabular}

Each value is an average of 20 determinations \pm standard deviation.

Values followed by the same letter in columns are not significantly different at $P<0.05$.

From previous results it could be concluded that, GA contain a high amount of dietary fiber and high percentage of phenolic compounds which act as antioxidant substances. The chemical composition of beef burger produced by replacing fat content with GA revealed that, protein and dietary fiber contents were increased with increasing replacement level, while fat content was decreased. The replacing fat content with GA improved the physical properties of low fat beef burger produced by increasing cooking yield and decreased cooking loss, shrinkage and diameter reduction. Cooking profile and sensory evaluation of low-fat beef burger showed that replacing level 5 and $10 \%$ gave values nearest to the control sample, also replacing levels 15 and $20 \%$ gave a fair product and not bad. So we can recommend using GA as fat replacer for production low-fat products for diabetic, obesity and hypercholestermic people.

\section{REFERENCES}

A.O.A.C., Association of Official Analytical Chemists (2005). Official Methods of Analysis of the Association of Official Analytical Chemists. $18^{\text {th }}$ Ed. Washington, DC, USA.

Abd El-Shakour, R.M. (2014). Evaluation the Effect of Gum Arabic for Treatment Chronic Renal Failure Patients. M.SC. Food Sci. Technol. Dept. Fac of Agric. Tanta Univ.

Al-Assaf, S., G.O. Phillips and P.A. Williams (2005). Studies on acacia exudate gums. Part 1: the molecular weight of Acacia senegal gum exudates. Food Hydrocoll. 19:647-660.

Aleson-Carbonell, L., J. FernandezLopez, J.A. Perez-Alvaez and V. Kuri (2005). Characteristics of beef burger as influenced by various types of lemon albedo. Inno. Food Sci. and Emer. Technol., 6:247-255.

Ali, B.H., A. Ziada and G. Blunden (2009). Biological effects of Gum Arabic: A 
review of some recent research. Food Chem. Toxicology, 47(1): 1-8.

American Meat Science Association. (1995). Research guidelines for cookery, sensory evaluation and instrumental tenderness measurements of fresh beef. American Meat Science Assoc., Chicago, U.S.A., 240pp.

Arabshahi-Delouee, S. and A. Urooj (2007). Antioxidant properties of various solvent extracts of mulberry (Morus indica L.) leaves. Food Chemistry, 102(4): 1233-1240.

Bessar, B. A. (2008). Effect of using orange and apple peel as fat replacers on the sensory, physical and nutritional evaluation of beef burgers. J. Agric. Res. Kafr El-Sheikh Univ., 34 (4): 1035-1056.

Bloukas, J.G., E.D. Panerase and G.C. Fournitzis (1997). Sodium lactate and protective culture effects on quality characteristics and shelf-life of low fat frankfurter produced with olive oil. Meat Science. 45:223-238.

Bourne, M. C. (2003). Food texture and viscosity: Concept and measurement. Elsevier Press, New Yourk/London.

Carrapiso, A. (2007). Effect of fat content on flavor release from sausages. Food Chemistry, 103(2): 396-403.

Choi, Y., J. Sung, J. Park, H.C. Lee, T.K. Jeon, C. J. Kim and Y. Kim (2016). Quality and sensory characteristics of reduced-fat chicken patties with pork back fat replaced by dietary fiber from wheat sprout. Korean Journal for Food Science of Animal Resources. 36:.799-806.

Daoub, R. M.A., A.H. Elmubarak, M. Misran, E.A. Hassan and E. A. Osman (2016). Characterization and functional properties of some natural Acacia gums. Journal of the Saudi Society of Agriculture Sciences, 1-9.
Dauqan, E. and A. Abdullah (2013). Utilization of Gum Arabic for industries and human health. American Journal of Applied Science, 10(10): 1270-1279.

Demirci, Z.O., I. Yilmaz and A.S. Demirci (2014). Effects of xanthan, guar, carrageenan and locust bean gum addition on physical, chemical and sensory properties of meatballs. Journal of food Science and Technology, 51(1): 936-942.

El-Seesy, T. A. (2000). Quality and safety of meat burger patties using "HACCP" System 3. Conference of "The Food Industry at the Serice of Turisum", April 112-14th Shrinkage-Cooking loss- Drip loss.

El-Abd, M.M., A.M. Abd El-Fattah, S.G. Osman and R.S. Abd El-Kader (2003). Effect of some lactic acid bacteria on the properties of low salt Domiati cheese. Egyptian Journal of Dairy Science, 31: 125-138.

El-Beltagy, A. E., E. A. Boudy and A. M. Gaafar (2007). Quality characteristics of low- fat beef patties formulated With Jerusalem artichoke (Helianthus tuberosus L.). J. Agric. Env. Sci. 6: 115.

El-Refai, A.A., A.R.M. El-Zeiny and Eman A.A. Abd-Rabo (2011). Effect of feeding on beef patties fortified with mushroom on serum lipids profile and liver enzymes of hypercholesterolmicrats. J. Food and Dairy Sci., Mansoura Univ., 2(3): 411428.

El-Tobgy, K.M.K. (2019). Protective role of Gum Arabic (Acacia Senegal) on oxidative stress in diabetic and adenine-induced chronic renal failure in rats. International Journal of Chem. Tech. Research, 12(1):223-234.

Gad, E.M.R. (2019). Utilization of Gum Arabic as Fat Replacers in Produce Low Fat Cake and Beef Burger. M.SC. 
Thesis; Nut and Fd Sci. Dept. Fac. Home Economics, Menoufia Univ.

Gibis, M., V. Schuh and J. Weiss (2015). Effects of carboxymethyl cellulose (CMC) and microcrystalline cellulose (MCC) as fat replacers on the microstructure and sensory characteristics of fried beef patties. Food Hydrocolloids, 45: 236-246.

Gilani, A.H., F. Shaheen and M. Zamanm (1999). Studies on antihypertensive antispasmodic activities of methanol extract of Acacia nilotica pods. 13: 665-669.

Gök, V., L. Akkaya, E. Obuz and S. Bulut (2011). Effect of ground poppy seed as a fat replacer on meat burgers. Meat Science, 89: 400-404.

Goupy, P., M. Hugues, P. Boivin and M.J. Amoit (1999). Antioxidant composition and activity of barley (Hordeum vulgare) and malt extracts and of isolated phenolic compounds. Journal of the Science of Food and Agriculture, 79: 1625-1634.

Hashem, Alyaa, M. A., K. M. E. Youssef, M.D. Mostafa and Magda A.A. Seliem (2011). The influence of frozen storage on physical and organoleptic properties of beef and low-fat beef burgers. Assiut J. of Agric. Sci., 42 (Special Issue )(The 5th Conference of Young Scientists Fac. of Agric. Assiut Univ. 8: 184-211.

Hussein, S. A., M.F.S.A. Shahin and M.R.M. Masoud (2015). Effect of using lemongrass and thyme on some beef burger characteristics. Egypt. J. Agric. Res., 93 (1):143-156

Khalifa, A.M. (2011). Physico-chemical, Microbiological and Organolyptic Characteristics of Beef burger as Affected by Addition of Potato Peel and Orange Albedo. Ph.D. Thesis. Food Sci. Technol. Dept., Fac. Agric., Tanta Univ .
Kılınççeker, O. and Ş. Kurt (2016). Effects of inulin, carrot and cellulose fibers on the properties of raw and fried chicken meatballs. South African. J. Animal Sci., 48(1).

Lee, S. C., J. H. Kim, S.M. Jeong, D. R. Kim, J. U. Ha and K. C. Nam (2003). Effect of far infrared radiation on the antioxidant activity of rice hulls. J. of Agric. and Food Chem., 51(15): 44004403.

Lim, J., G. E. Inglett and S. Lee (2010). Response to consumer demand for reduced-fat foods; Multi-Functional Fat Replacers. Japan Journal of Food Engineering, $\Pi$ (4): 147-152.

Liu, H., X.M. Xu and S.H. Guo (2007). Rheological texture and sensory properties of low-fat mayonnaise with different fat mimetics. LWT, 40:946954.

Mahmoud, M.H., A.A. Abou-Arab and Ferial M. Abu-Salem (2017). Quality Characteristics of Beef Burger as Influenced by Different Levels of Orange Peel Powder. Am. J. Food Technol., 12: 262-270.

Malviya, S., R. Rawat, M. Verma and A. Kharia (2011). Prelimiary phytochemical investigation of Acacia nilotica Linn plant. Curpharm, Res 1(2):91-100.

Mansour, E. H. and A. H. Khalil (1997). Characteristics of low-fat beef burger as influenced by various types of wheat fibers. Food Research International, 30: 199-205.

Mun, S., Y.L. Kim, C.G. Kang, K.H. Park, J.Y. Shim and Y.R. Kim (2009). Development of reduced fat mayonnaise 4aGTase-modified rice starch and xanthan gum. International Journal of Biological Macromolecules, 44:440-407.

Mwove, J. K., L. A. Gogo, B. N. Chikamai, M. N. Omwamba and S. M. Mahungu (2016). Preparation and quality 
evaluation of extended beef rounds containing gum Arabic from Acacia senegal var. kerensis. Food and Nutrition Sciences, 7(11): 977.

Namir, M., H. Siliha and M. F. Ramadan (2015). Fiber pectin from tomato pomace: characteristics, functional properties and application in low-fat beef burger. Journal of Food Measurement and Characterization, 9(3): 305-312.

Nasir, O., A.T. Umbach, R. Rexhepaj, T.F. Ackermann and M. Bhandaru (2012). Effects of Gum Arabic (Acacia Senegal) on renal function in diabetic mice. Kidney Blood Press Res, 35:365372.

Pearson, D. (1991). The chemical analysis of food. National College of Food Technology, University of Reading, Weybridge. Surry, T. and A. Churchill

Pereira, A.G.T., E.M. Ramos, J.T. Teixeira, G.P. Cardoso, A.L. Ramos and P.R. Fontes (2011). Effects of the addition of mechanically debonded poultry meat and collagen fiber on quality characteristics of frankfurter-type sausages. Meat Sci., 89:519-525.

Ramadhan, K., N. Huda and R. Ahmad (2011). Physicochemical characteristics and sensory properties of selected Malasyian commercial chicken burgers. Int. Food Res. Res. J., 18:1349-1357.

Rather, S.A., F.A. Masoodi, R. Akhter, A. Gani, S.M. Wani and A.H. Malik (2016). Effects of guar gum as fat replacer on some quality parameters of mutton goshtaba, a traditional Indian meat product. Small Rum Res 137:169-176.

Sabah El-Kheir, M.K., A.E.G. A. Yagoub and A.A. AbuBaker (2008). Emulsionstabilizing effect of gum from Acacia senegal (L) willd. The role of quality and grade of gum, oil type, temperature, stirring time and concentration. Pakistan Journal of Nutrition, 7(3):395-399.

Shalaby, M.T., A.M. Hassn, N.A. El-Boraey and Mona M. El-Shahat (2015). Quality attributes of some sausage likeproducts. J. Food and Dairy Sci., Mansoura Univ., 6 (2): 101 - 117.

Simela, L. (2005). Meat characteristics and acceptability of chevron from South Africa indigenous goat. Ph.D. Thesis. Univ. of Pretoria, South Africa.

Smith, G.C., Z.L. Carpenter, K.K.F. Mittal and C.M. Cater (1973). Efficacy of protein additives as emulsion stabilizer in frankfurter. J. Food Sci., 38: 849-855.

Soncu, E.D., N. Kolsanci, N. Peek, G.S. Ozttirk, L.T. Akpglu and Y.K. Arici (2015). The comparative effect of carrot and lemon fiber as a fat replacer on physicochemical, textural and organoleptic quality of low-fat beef hamburger. Korean J. Food Sci. Anim Resour, 35(3): 370-381.

SPSS. (2009). PASW STATISTICS (18) Command Syntax Reference. SPSS Inc., USA.

Tsolaze, E. A. (1972). The relationship between the tenderness of fish meat and its protein water and protein water fat coefficients. Fish Industry, 48 (7): 68 - 69.

Williams, P.A. and G.O. Phillips (2000). "Gum Arabic" In: Handbook of Hydrocolloids, G.O. Phillips and P.A. Williams (Eds.). Cambridge (UK): Woodhead Publishing.

Yeo, E., H. Kim, K. Hwang, D. Song, Y. Kim, Y. Ham, F. He, J. Park and C. Kim (2014). Effect of duck feet gelatin on physicochemical, textural and sensory properties of low-fat Frankfurters. Korean J. Food Sci. An, 34(4): 415-422. 
إنتاج بورجر منخفض الدهن باستخدام الصمغ العربي كبديل للاهن

محمود إمام السيد(')، أشرف شعبان بكر (')، أحمد محمد جعفر (ץ)، عواطف إبرههيم إسماعيل(r)،

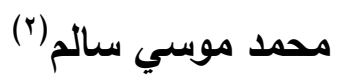

(1) قسم علوم وتكنولوجيا الأغذية - كلية الزراعة- جامعة طنطا

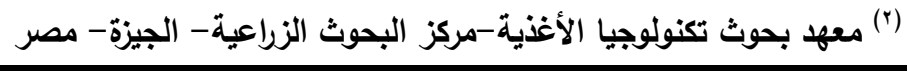

الملخص العربي

تم دراسة التركيب الكيماوي والمركبات الفينولية والنشاط المضاد للأكسدة للصمغ العربي بالإضافة إلي الصفات الطبيعية والكيماوية وصفات الطبخ والصفات الحسية للبورجر منذفض الدهن الذي تم تصنيعه بإستبدال جزء من المحتوي

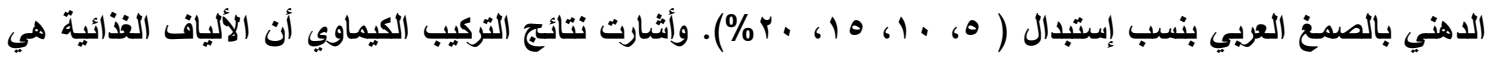

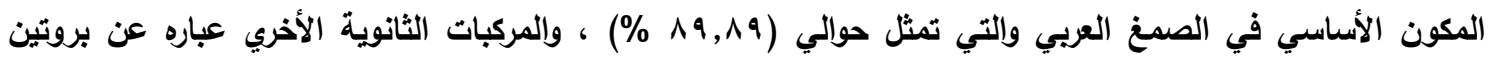

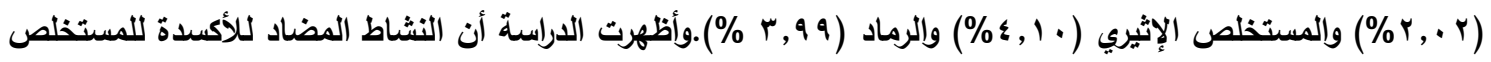

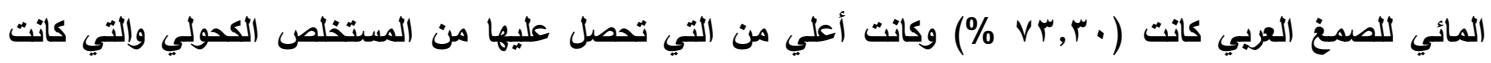

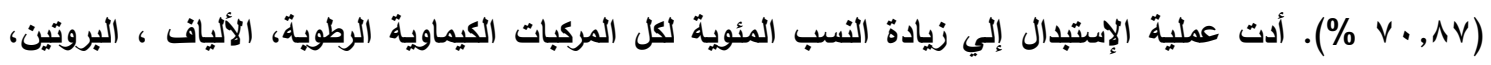
الرماد، الكريوهيدرات الكلية بإستثاء المستخلص الإثيري الأي حدث له إنخفاض في كلا من البورجر الخام والبورجر

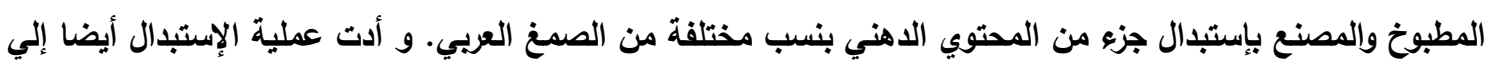
زيادة معنوية في القدرة علي الإحتفاظ بالرطوية وقيمة feder value في حين إنخفضت البلاستيكية ومعامل البروتين

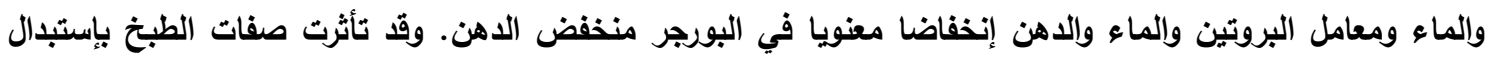

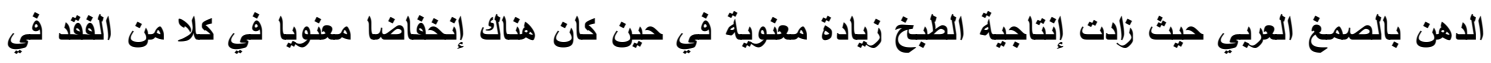

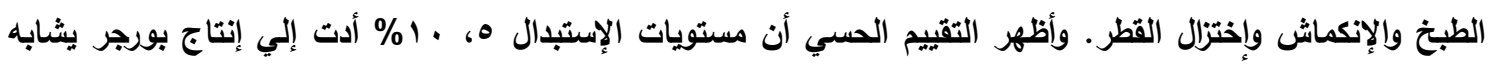

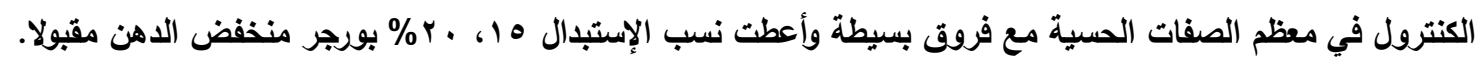


M.E. El-Sayed, et al., 